\title{
The Effect of Ethidium Bromide Mutagenesis on Dimorphism, Extracellular Metabolism and Cytochrome Levels in Aureobasidium pullulans
}

\author{
By PATRICK J. KELLY* AND BRIAN J. CATLEY \\ Department of Brewing and Biological Sciences, Heriot-Watt University, \\ Edinburgh $E H$ I I $H X$
}

(Received 7 February 1977; revised 3 May 1977)

\begin{abstract}
Treatment of the dimorphic fungus Aureobasidium pullulans with ethidium bromide resulted in the production of several mutants, cultures of which produce an increased proportion of yeast-like cells. A comparison of several mutant isolates with the wild type suggested that the yeast-like cell is responsible for the production of the polysaccharide, pullulan. Mutation was also shown to affect other metabolic patterns, e.g. the reduced accumulation of extracellular ethanol by the mutant. The cytochrome components of the respiratory chain in the wild type were examined by whole-cell spectrophotometry and compared with those of the mutants; the latter had a decreased cytochrome content.
\end{abstract}

\section{INTRODUCTION}

Dimorphic fungi such as Paracoccidioides brasiliensis (Carbonell, Kanetsuna \& Gil, I970), Mucor rouxii (Bartnicki-Garcia, 1963) and Candida albicans (Chattaway et al., I973) are being used increasingly as experimental material in the study of microbial differentiation. These organisms are capable of growing either as a hypha or in a unicellular yeast-like form. The deuteromycete Aureobasidium pullulans has been studied for a number of years as the source of a novel extracellular polysaccharide, pullulan, and the conditions affecting synthesis of the polysaccharide have been examined (Bender, Lehmann \& Wallenfels, 1959; Catley, I971, I973). This fungus has been described as being dimorphic (Cooke, 1959) though in reality the sequence of transformations undergone by the organism is more complex (Ramos \& Garcia-Acha, 1975). In this laboratory we have been examining metabolic events associated with the differentiation of this organism in liquid culture, e.g. the metabolism of pullulan, trehalose and ethanol have been investigated (Kelly \& Catley, 1976; Catley \& Kelly, 1975; Carolan, Catley \& Kelly, 1976).

Recent experiments with Mucor and Mycotypha have demonstrated a relationship between dimorphism and the respiration-fermentation balance (Hall \& Kolankaya, 1974). Environmental conditions which lead to an impairment of respiratory function, e.g. high glucose concentration, $\mathrm{KCN}$ and oligomycin, also lead to an increase in the number of yeast-like organisms. Spontaneous and ultraviolet light-induced mutants have also been isolated. These mutants show an impaired respiratory chain and grow entirely in the yeast-like phase (Storck \& Morrill, I97I; Schulz, Kraepelin \& Hinkelmann, 1974).

Because there is accumulating evidence that the elaboration of pullulan is associated with the yeast-like phase of $A$. pullulans (Catley, 1973; Catley \& Kelly, 1975), we decided to investigate the possibility of producing mutants of $A$. pullulans which grew with an increased

* Present address: Department of Developmental Biology, Boston Biomedical Research Institute, 20 Staniford Street, Boston, Massachusetts 021 I4, U.S.A. 
proportion of single cells in the hope that there would be a concomitant increase in the amount of pullulan produced. For this purpose we selected the mutagen ethidium bromide (2,7-diamino-10-ethyl-9-phenylphenanthridinium bromide) which is thought to have a selective action on circular DNA, such as mitochondrial DNA in eukaryotic cells, in order to suppress the growth of the presumed respiratory mycelium.

\section{METHODS}

Organism and culture conditions. Aureobasidium pullulans strain ATcc9348 was grown in medium of the following composition: glucose, $250 \mathrm{mM} ; \mathrm{KCl}, 5.0 \mathrm{~mm} ; \mathrm{MgCl}_{2}, 4.0 \mathrm{~mm} ; \mathrm{Na}_{2} \mathrm{SO}_{4}, 4.0 \mathrm{~mm} ; \mathrm{Na}_{2} \mathrm{HPO}_{4}$ and $\mathrm{NaH}_{2} \mathrm{PO}_{4}, 20 \mathrm{mM} ; \mathrm{NH}_{4} \mathrm{Cl}, 20 \mathrm{mM} ; \mathrm{FeCl}_{3} .6 \mathrm{H}_{2} \mathrm{O}, 2.0 \mu \mathrm{M} ; \mathrm{MnCl}_{2} .4 \mathrm{H}_{2} \mathrm{O}, 2.0 \mu \mathrm{M} ; \mathrm{ZnCl}_{2}, 2.0 \mu \mathrm{M} ; \mathrm{CaCl}_{2}$, $50 \cdot 0 \mu \mathrm{M} ; \mathrm{CuSO}_{4} \cdot 5 \mathrm{H}_{2} \mathrm{O}, 0.2 \mu \mathrm{M}$; and yeast nitrogen base (Difco) $0.65 \%(\mathrm{w} / \mathrm{v})$. An inoculum was prepared by suspending the organism, grown on potato dextrose agar, in sterile water. The inoculum was grown in $100 \mathrm{ml}$ of the above medium for $48 \mathrm{~h}$ at $25^{\circ} \mathrm{C}$ and $2 \mathrm{ml}$ of this culture was then used to inoculate a further $100 \mathrm{ml}$ of medium.

Mutagenesis. A sample ( $10 \mathrm{ml}$ ) of an $18 \mathrm{~h}$ culture was transferred aseptically to $90 \mathrm{ml}$ of the standard medium containing $40 \mu \mathrm{g}$ ethidium bromide $\mathrm{ml}^{-1}$. The culture was incubated at $22{ }^{\circ} \mathrm{C}$ for $4 \mathrm{~h}$, centrifuged $(5000 \mathrm{~g}, 10 \mathrm{~min})$ and washed in sterile growth medium without glucose. Samples were removed, spread on $2 \%(w / v)$ agar plates containing the standard growth medium and incubated at $25^{\circ} \mathrm{C}$ for 3 days. Those colonies displaying an apparent increase in the proportion of yeast-like cells were replated.

Analytical methods. Cell dry weights were determined by passing culture samples through pre-weighed cellulose acetate filters (Millipore, $0.8 \mu \mathrm{m}$ pore size), washing the filters with ice-cold distilled water and drying them in vacuo at $45^{\circ} \mathrm{C}$. Yeast-like cells were counted in a Thoma haemocytometer. Extracellular polysaccharide was precipitated from cell-free supernatant samples by adding 2 vols ethanol. The samples were stored overnight at $4{ }^{\circ} \mathrm{C}$ and the precipitate was collected and washed with $66 \%(\mathrm{v} / \mathrm{v})$ ethanol until free of glucose. The polysaccharide was redissolved in distilled water at $100^{\circ} \mathrm{C}$. Total carbohydrate was determined by the phenol-sulphuric acid method (Dubois et al., 1956); pullulan was estimated with pullulanase (Catley, 1971). Ethanol was determined by gas-liquid chromatography of $I \mu l$ supernatant samples using,a Perkin-Elmer gas chromatograph (model FI7), with detector, injector and oven temperatures of 187,270 and $60^{\circ} \mathrm{C}$, respectively, and a stationary phase of $15 \%$ carbowax 1500 on florisil.

Whole-cell spectrophotometry. Organisms were either grown as described above or in the same medium containing $55 \mathrm{~mm}$-glucose for $18 \mathrm{~h}$ at room temperature. Samples were removed from both cultures and centrifuged ( $10000 \mathrm{~g}, 10 \mathrm{~min})$. The cells were then resuspended in a small quantity of distilled water to form a heavy cell paste and the suspension was divided between two $\mathrm{I} \mathrm{cm}$ path-length cuvettes. Difference spectra were taken for the two cuvettes using a split-beam spectrophotometer (Haddock \& Garland, 1971) with (i) no additions in order to obtain a baseline, (ii) $\mathrm{H}_{2} \mathrm{O}_{2}$ added to one cuvette to obtain a reduced-oxidized difference spectrum. Whole-cell protein was determined by the method of Miller (1959). The extinction coefficients used in the calculation of cytochrome concentrations are those given by Boveris et al. (197I).

\section{RESULTS}

Ethidium bromide mutagenesis yielded several colonies which appeared to exhibit a higher proportion of yeast-like cells. Three were selected, designated $\mathrm{Y}_{3}, \mathrm{Y}_{7}$ and $\mathrm{Y}_{8}$, and their growth, cell-type and polysaccharide production were compared with the wild type (Figs I and 2). Although the increase in cell dry weight was similar for all four isolates the number of yeast-like cells produced differed markedly. Moreover, Fig. 2 shows that the number of yeast-like cells was closely related to the concentration of extracellular polysaccharide, a product which has pullulan as a major component. The nature of the remaining extracellular polysaccharide(s) is not known but is currently under investigation.

Whole-cell cytochrome scans for the wild type and mutant isolates of $A$. pullulans are shown in Fig. 3. Absorbance maxima of the difference spectrum were found at about 425 , $445,522,552$ and $612 \mathrm{~nm}$. The peak at $425 \mathrm{~nm}$ probably represents a combination of the $\gamma$ absorption bands for cytochromes $b$ and $c$, and the peak at $445 \mathrm{~nm}$ the absorption band for $c$-type cytochromes with a contribution from cytochrome $b$ at about $560 \mathrm{~nm}$. The absorption peak at $6 \mathrm{I} 2 \mathrm{~nm}$ represents the $\alpha$ absorption band for cytochromes $a+a_{3}$. Most 

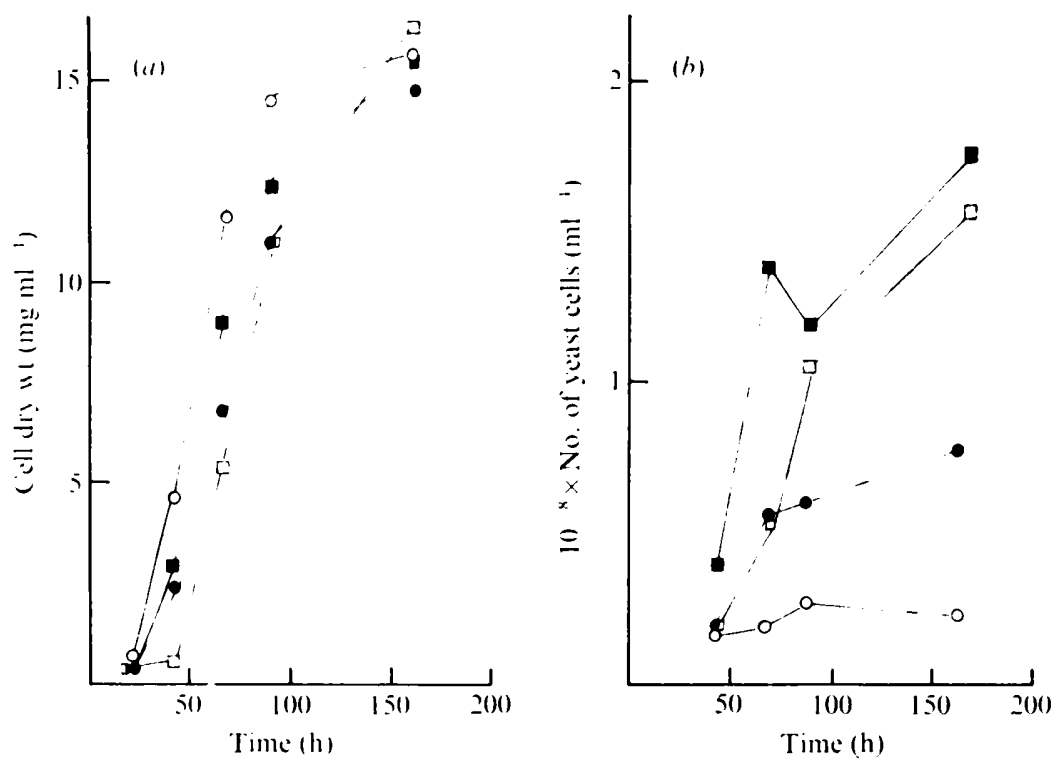

Fig. I. (a) The increase in cell dry weight and $(b)$ the accumulation of yeast-like organisms by A. pullulans. $O$, Wild type; $\bigcirc$, mutant $\mathrm{Y}_{3} ; \square$, mutant $\mathrm{Y}_{7} ; \square$, mutant $\mathrm{Y}_{8}$.
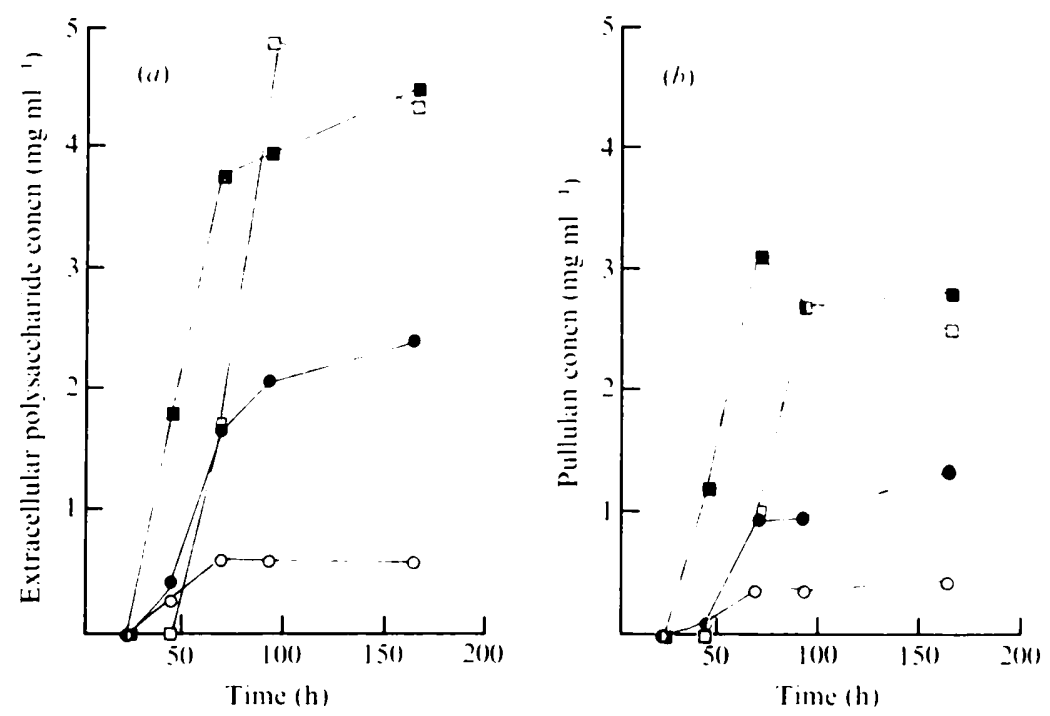

Fig. 2. The accumulation of $(a)$ total extracellular polysaccharide and $(b)$ pullulan by $A$. pullulans. Symbols as in Fig. I.

cytochrome scans show a pronounced negative trough at about $475 \mathrm{~nm}$ representing the flavoprotein components of the respiration chain. This trough was much less pronounced in $A$. pullulans. Again, published scans show the relative intensities of the absorption peaks at $425 \mathrm{~nm}$ and $445 \mathrm{~nm}$ to be the reverse of that found in $A$. pullulans. The concentrations of the $a, b$ and $c$-type cytochromes were calculated (Table I) and may be compared with the values given for Candida parapsilosis by Kellerman, Biggs \& Linnane (1969). Ethidium bromide mutagenesis led to a decrease in the level of cytochromes, particularly cytochromes $a+a_{3}$. This is also found in Saccharomyces cerevisiae (Slonimski, Perrodin \& Croft, 1968). 

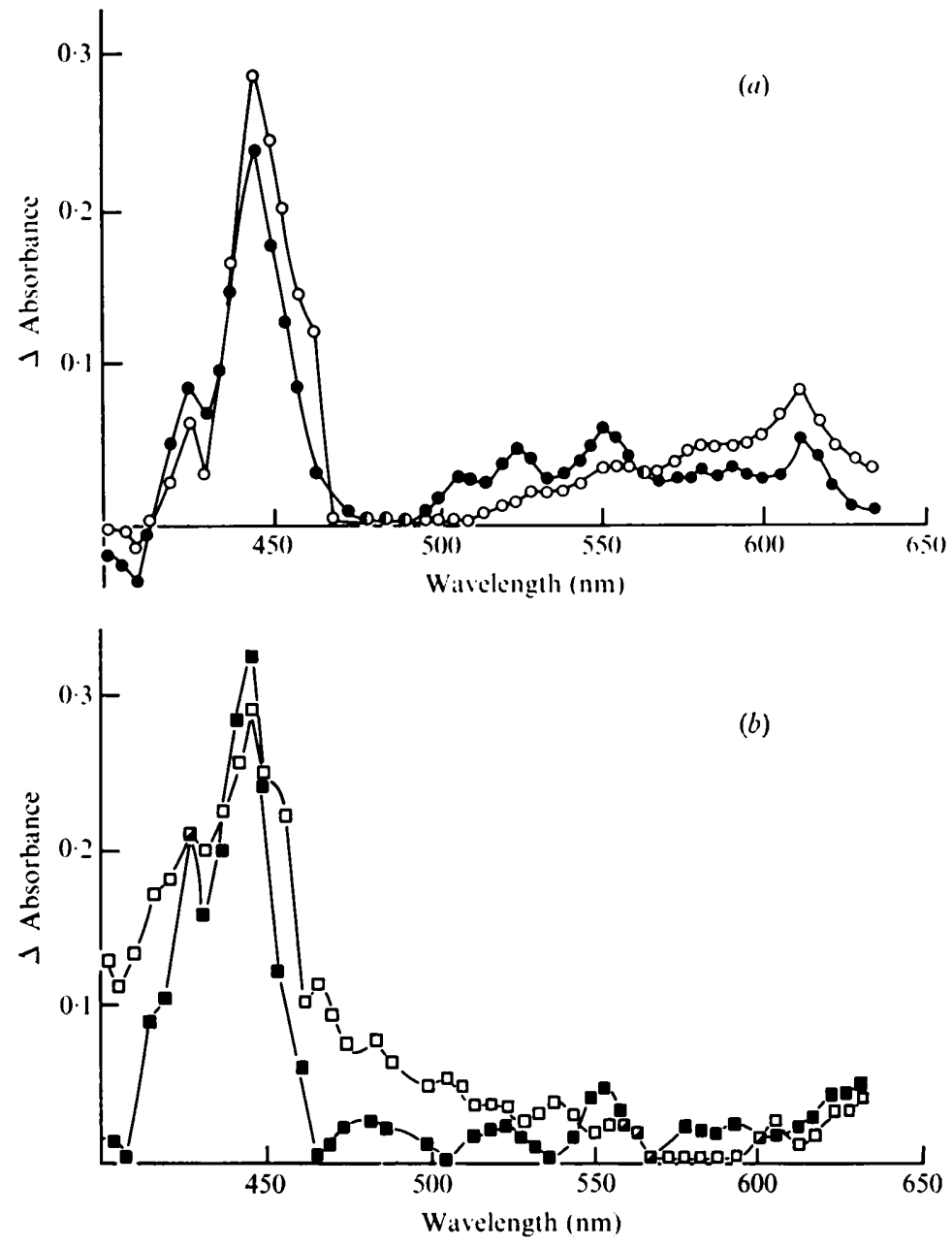

Fig. 3. Whole-cell spectra of $A$. pullulans with $\mathrm{H}_{2} \mathrm{O}_{2}$ added to one cuvette to obtain a reducedoxidized difference spectrum. (a) Wild type and mutant $Y_{3} ;(b)$ mutants $Y_{7}$ and $Y_{8}$. Symbols as in Fig. 1.

Table I. Cor.centration of $a, b$ and c-type cytochromes in A.pullulans and mutants derived by treatment with ethidium bromide

Whole-cell difference spectra were obtained from oxidized/reduced cells (Fig. 3) and the profiles were used to calculate the cytochrome contents.

\begin{tabular}{|c|c|c|c|}
\hline \multirow[b]{2}{*}{ Organism } & \multicolumn{3}{|c|}{$\begin{array}{c}10^{8} \times \text { Cytochrome content } \\
{\left[\mathrm{mol}(\mathrm{g} \text { whole-cell protein })^{-1}\right]}\end{array}$} \\
\hline & $b$ & $c+c_{1}$ & $a+a_{3}$ \\
\hline $\begin{array}{l}\text { A. pullulans } \\
\text { Mutant Y8 } \\
\text { Mutant Y7 }\end{array}$ & $\begin{array}{l}3 \cdot 2 \\
2 \cdot 4 \\
2 \cdot 4\end{array}$ & $\begin{array}{l}5.2 \\
2.8 \\
2.9\end{array}$ & $\begin{array}{l}6.6 \\
0.6 \\
0.8\end{array}$ \\
\hline Mutant Y3 & 3.4 & 3.9 & $3 \cdot 5$ \\
\hline Candida parapsilosis* & 13.0 & $20 \cdot 0$ & $7 \cdot 0$ \\
\hline
\end{tabular}

- Data from Kellerman et al. (1969). 
A plot of the number of yeast-like cells produced by these mutants against their cytochrome $a+a_{3}$ content showed an inverse relationship.

Further comparisons of the wild type and mutant Y8 were undertaken. The rates of increase in cell dry weight were again similar, as were the rates of glucose uptake $(0.20 \mu \mathrm{mol}$ $\mathrm{mg}^{-1} \mathrm{~h}^{-1}$ for the wild type and $0.16 \mu \mathrm{mol} \mathrm{mg}^{-1} \mathrm{~h}^{-1}$ for Y8). However, the wild-type culture excreted ethanol into the medium with the concentration rising to $43 \mathrm{mM}$ whereas ethanol could not be detected in the mutant Y8 culture at any stage of growth.

\section{DISCUSSION}

Of the mutants produced by the treatment of $A$. pullulans with ethidium bromide, three were selected for their apparent increase in yeast-like growth on agar plates. A comparison of the yeast cell numbers and cell dry weights with those of the untreated organism showed that the proportion of growth in the yeast-like form was considerably greater in the mutants. The finding that ethidium bromide treatment produces mutants with decreased amounts of hyphae might suggest that the mycelial growth of $A$. pullulans is dependent on mitochondrial function, since the action of the mutagen is thought to result in the impairment of transcription from the circular duplex of mitochondrial DNA (Radloff, Bauer \& Vinograd, 1967). Ethidium bromide, however, affects other cellular functions and its actions may be more complex (Azzi \& Santato, 197I; Jones \& Kearns, 1975). Whatever the action of the mutagen, its effect on $A$. pullulans is to shift the balance of growth from the mycelial to the yeast phase.

Investigations of dimorphism in Mycotypha (Storck \& Morrill, I97 I ; Schulz et al., 1974; Hall \& Kolankaya, I974) have demonstrated a relationship between dimorphism and the respiration-fermentation balance. It was therefore decided to see if there might not be a similar connexion between these metabolic alternatives and the morphological change observed in $A$. pullulans. The cytochrome content of the mutant yeast cells is considerably reduced, suggesting that respiration may not be necessary for the functioning of the yeast cell but is necessary for the viability of the mycelium. However, for glycolysis to take place, a fermentative metabolism requires the production of some compound reduced by NADH. Whilst there is considerable production of ethanol during growth of the wild type, with the concentration exceeding $40 \mathrm{~mm}$ (Catley \& Kelly, 1975; Carolan et al., 1976), there was no detectable ethanol at any point of the growth cycle of mutant Y8. Contrary to the above, this indicates either a respiratory metabolism for the mutant yeast or a fermentation product that is not ethanol. The levels of cytochromes are reduced, but not absent, and may be sufficient for adequate respiration.

Evidence has been presented (Catley, 1973; Catley \& Kelly, 1975) that the production of pullulan occurs in the early-stationary phase of the growth cycle and is concomitant with a change of morphology by the organism from mycelial to yeast-like growth. The results presented here show that an increased production of yeast cells by the organism is paralleled by an increased production of pullulan, again linking the elaboration of the extracellular polysaccharide to the yeast cell.

We are currently investigating the balance between oxidative and fermentative metabolism in the wild type and mutant organisms in the hope of establishing further links between morphology, glucose utilization patterns and pullulan production in $A$. pullulans.

We thank the Science Research Council for a graduate studentship to P.J.K., and Professor P. B. Garland for access to the spectrophotometer used in these studies. Dr B. Haddock is also thanked for his help in the interpretation of the difference spectra. 


\section{REFERENCES}

AzzI, A. \& Santato, M. (1971). Interaction of ethidium with the mitochondrial membrane: cooperative binding and energy-linked changes. Biochemical and Biophysical Research Communications 44, $211-217$.

Bartnicki-Garcia, S. (1963). Symposium on the biochemical bases of morphogenesis in fungi. III. Mold-yeast dimorphism of Mucor. Bacteriological Reviews 27, 293-304.

Bender, H., LehmanN, J. \& Wallenfels, K. (1959). Pullulan, ein extracelluläres Glucan von Pullularia pullulans. Biochimica et biophysica acta36, 309-316.

Boveris, A., Oshino, R., Evecińska, M. \& Chance, B. (1971). Reduction of mitochondrial components by durohydroquinone. Biochimica et biophysica acta 245, I-16.

Carbonell, L. M., Kanetsuna, F. \& Gil, F. (1970). Chemical morphology of glucan and chitin in the cell wall of the yeast phase of Paracoccidioides brasiliensis. Journal of Bacteriology IOI, 636-642.

Carolan, G., Catley, B. J. \& Kelly, P. J. (1976). Ethanol production during the growth cycle of Aureobasidium pullulans. Biochemical Society Transactions 4, $1021-1022$.

Catley, B. J. (197I). Role of pH and nitrogen limitation in the elaboration of the extracellular polysaccharide pullulan by Pullularia pullulans. Applied Microbiology 22, 650-654.

CATLEY, B. J. (1973). The rate of elaboration of the extracellular polysaccharide, pullulan, during growth of Pullularia pullulans. Journal of General Microbiology 78, 33-38.

Catley, B. J. \& Kelly, P. J. (1975). Metabolism of trehalose and pullulan during the growth cycle of Aureobasidium pullulans. Biochemical Society Transactions 3, 1079-1081.

Chattaway, F. W., Bishop, R., Holmes, M. R., Odds, F. C. \& Barlow, A. J. E. (1973). Enzyme activities associated with carbohydrate synthesis and breakdown in the yeast and mycelial forms of Candida albicans. Journal of General Microbiology 75, 97-109.

CoOKe, W. B. (1959). An ecological life history of Aureobasidium pullulans (De Barry) Arnaud. Mycopathologica et mycologia applicata 12, 1-45.

Dubois, M., Gilles, K. A., Hamilton, J. K., Rebers, P. A. \& Smith, F. (1956). Colorimetric method for the determination of sugars and related substances. Analytical Chemistry 28, 350-357.
HADDOCK, B. A. \& GaRland, P. B. (1971). Effect of sulphate-limited growth on mitochondrial electron transfer and energy conservation between reduced nicotinamide-adenine dinucleotide and the cytochromes in Torulopsis utilis. Biochemical Journal 124, $155-170$.

Hall, M. J. \& Kolankaya, H. (1974). The physiology of mould-yeast dimorphism in the genus Mycotypha (Mucorales). Journal of General Microbiology 82, 25-34.

JONES, C. R. \& KEARNS, D. R. (1975). Identification of a unique ethidium bromide binding site on yeast t-RNA ${ }^{\text {Phe }}$ by high resolution $(300 \mathrm{MHz})$ nuclear magnetic resonance. Biochemistry 14, 2660-2665.

Kellerman, G. M., Biggs, D. R. \& Linnane, A. W. (I969). Biogenesis of mitochondria. XI. A comparison of the effects of growth limiting oxygen tension, intercalating agents and antibiotics on the obligate aerobe Candida parapsilosis. Journal of Cell Biology 42, 378-391.

Kelly, P. J. \& CATLey, B. J. (1976). A purification of trehalase from baker's yeast. Analytical Biochemistry 72, 353-359.

Miller, G. L. (1959). Protein determination for large numbers of samples. Analytical Chemistry 31, 965.

RADloff, R., BAUER, W. \& VINOGRAD, J. (I967). A dye-buoyant-density method for the detection and isolation of closed circular duplex DNA: the closed circular DNA in HeLa cells. Proceedings of the National Academy of Sciences of the United States of America 57, 1514-1521.

Ramos, S. \& Garcia-Acha, I. (1975). A vegetative cycle of Pullularia pullulans. Transactions of the British Mycological Society 64, 129-135.

Schulz, B. E., Kraepelin, G. \& HinkelmanN, W. (1974). Factors affecting dimorphism in Mycotypha (Mucorales): a correlation with the fermentation/ respiration equilibrium. Journal of General Microbiology 82, I-1 3.

Slonimski, P. P., Perrodin, G. \& Croft, J. H. (I968). Ethidium bromide induced mutation of yeast mitochondria: complete transformation of cells with respiratory deficient non-chromosomal 'petites'. Biochemical and Biophysical Research Communications 30, 232-239.

STORCK, R. \& MoRRILl, R. C. (1971). Respiratorydeficient yeast-like mutant of Mucor. Biochemical Genetics 5, 467-479. 